\title{
Choroid Plexus Epithelium of the Fourth Ventricle
}

National Cancer Institute

\section{Source}

National Cancer Institute. Choroid Plexus Epithelium of the Fourth Ventricle. NCI

Thesaurus. Code C49230.

The epithelium of the choroid plexus at the fourth ventricle; which consists of cuboidal cells. 